\title{
JUURNAL.RU
}

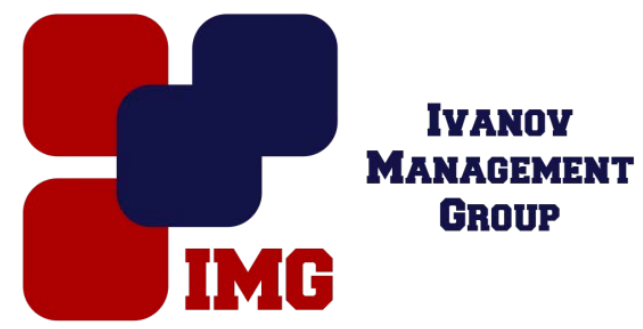

Калимуллина А.И. Федеральное государственное автономное образовательное учреждение выстего образования «Казанский (Приволжский) Федеральный Университет» Казань, Россия

doi: 10.18411/lj-30-11-2016-3-08

idsp 000001:lj-30-11-2016-3-08

\section{Проблемы управления затратами}

\section{Аннотация}

В данной статье раскрыта целесообразность организации системы управления затратами организации и рассмотрены ее основные функции. Помимо этого выявлены основные проблемы, препятствующие формированию эффективной системы управления затратами.

Ключевые слова: затраты, управление, система управления.

\section{Abstract}

In this article considers the feasibility of establishing a system of cost management of the organization and its main functions. In addition, considers the main problems impeding the development of effective cost management system.

Keywords: costs, management, management system.

В период развития рыночных отношений многие предприятия стремились к росту рентабельности деятельности путем повышения отпускных цен на выпускаемую продукцию. В настоящее время наблюдается жестокая конкуренция во всех отраслях экономики, что требует поиска новых путей повышения эффективности экономической деятельности организаций, где одним из главных решений становится управление затратами, позволяющее снизить цены на производимые продукции, тем самым давая возможность компаниям сохранять на рынке свои позиции.

Управление затратами представляет собой динамический процесс, включающий управленческие действия, целью которых является достижение высокого экономического результата деятельности предприятия. Управление затратами, прежде всего, предполагает целенаправленное формирование затрат по их видам, местам и носителям, а также их постоянный контроль и стимулирование в сторону их уменьшения. 
Система управления затратами - это многоуровневая система, в котором объектом управления являются затраты компании, а субъектом управления выступает управляющая система. Сам механизм управления составляет совокупность его функций, т.е. управление затратами реализуется через различные функции.

Среди ученых существуют совершенно различные мнения по системе управления затратами. Так, Г.А. Краюхин выделяет три функции управления: разработку решений, реализацию решений, контроль, а общепринятые функции называет элементами управленческого цикла (прогнозирование, планирование, организация, координация и регулирование, активизация и стимулирование, учет и анализ). Р.А. Фатхутдинов выделяет три функции управления: маркетинг, планирование, управление персоналом. А. Файоль - основоположник западного менеджмента - выделяет шесть функций: техническую, коммерческую, финансовую, страховую, учетную, административную. П.П. Лабзунов к общепринятым в российской экономике пяти функциям добавляет функции учета, калькулирования и анализа [1].

Придерживаясь мнения большинства ученых, можно выделить следующие основные функции управления затратами:

- поиск и выявление факторов экономии ресурсов;

- нормирование затрат ресурсов;

- планирование затрат ресурсов по их видам;

- учет и анализ затрат ресурсов;

- стимулирование экономии и ресурсов и снижение их расхода.

Однако организация системы управления затратами не в полной мере способствует решению проблем их оптимизации и эффективности хозяйствования организаций, что связано с методикой анализа, планирования, стимулирования затрат. Существующая в настоящее время система бухгалтерского (финансового) учета и отчетности не может в достаточной степени обеспечить руководство организации информации, необходимых для принятия эффективных управленческих решений [2].

Управление затратами предполагает знание причин, влияющих на их уровень и динамику. В специальной экономической литературе известны различные методы пофакторного планирования динамики затратных показателей. Но мнение ученых о системе факторов также разнообразны. Тем не менее на практике этому вопросу не уделяется должного внимания, что ведет к определенным сложностям у предприятий в решении проблем управления, не давая возможности сформировать эффективную систему управления затратами.

Таким образом, среди основных проблем управления затратами является отсутствие в использовании в организации теоретических и практических аспектов управления затратами, способствующих в организации процесса управления. Помимо этого, проблема управления затратами связана с многообразием различных видов расходов, что требует дополнительного 
изучения их классификационных особенностей для дальнейшего обобщения с целью оптимизации постановки управленческого учета.

Управленческий учет является одним из главных инструментов управления затратами, включающий в себя сбор, анализ, планирование и контроль данных о затратах организации. Правильно поставленный управленческий учет способствует выявлению недостатков и недочетов в деятельности предприятия, предоставляя решения для устранения возникших проблем [3, с. 52]. В рамках разработки эффективной системы управленческого учета необходимо правильно интегрировать различные методы учета затрат [4]. Важно сочетать инструменты стратегического и оперативного управленческого учета. Примером такой взаимосвязи служит учет целевых нормативных затрат [5]. Особое значение имеет разработка схем отражения затрат на счетах управленческого учета, например с использованием группы 30-х счетов [6].

Современные экономические условия хозяйствования при разработке механизма управления затратами требуют раздельного учета доли условнопостоянных и переменных затрат. Такое разделение связано с тем, что величина прибыли и порог рентабельности, при котором производство не имеет прибыли, но уже безубыточно, зависят от соотношения указанных затрат в общей их сумме. На практике же не все предприятия ведут данный учет. Тем самым, следующей проблемой в управлении затратами является в невозможности точного измерения состава и группы затрат, оказывающих существенное влияние на деятельность организации.

Еще одной проблемой в управлении затратами определяется неоднозначным влиянием затрат на финансовый результат экономического субъекта в целом, который выражается бухгалтерской прибылью (убытком). Именно от применяемой системы учета затрат зависит, в каком отчетном периоде та или иная затратная статья повлияет на величину бухгалтерской прибыли, т.е. станет расходом [7].

Таким образом, современным предприятиям, с целью увеличения своей прибыльности и во избежание риска банкротства, необходимо создавать системы управления затратами. Внедрение такой системы потребует дополнительных расходов, что предполагает радикальное преобразование всей системы управления предприятием, включающее в себя совершенствование документооборота, переход к более новым информационным технологиям, изменение организационной и функциональной структуры организации. Такие преобразования в будущем приведут к существенным улучшениям в области управления затратами. 


\section{Литература}

1. Ивашкевич В.Б. Организация управленческого учета по центрам ответственности и местам формирования затрат // Бухгалтерский учет. - 2008. - № 5. - С. 56-59.

2. Головина С. В., Парамонова Д. В. Актуальные проблемы управления затратами в современных компаниях // Молодой ученый. - 2015. №11.3. - С. 32-34.

3. Сайфиева С.Н. Проблемы управления затратами и результатами производства: Дисс. канд. эконом.наук /Сайфиева С.Н. - Москва, 2003. - $155 \mathrm{c}$.

4. Соколов А.Ю. Направления развития управленческого учета / А.Ю. Соколов // Вестник Казанского государственного финансовоэкономического института. - 2008. - № 2, с. 47-51.

5. Соколов А.Ю. Учет целевых нормативных затрат / А.Ю. Соколов // «Бухгалтерский учет». - 2007. - № 4, С. 76-79.

6. Соколов А.Ю. Особенности учета затрат с использованием группы 30-х счетов на примере нефтехимического предприятия / A.Ю. Соколов, И.Р. Яхин // Все для бухгалтера. - 2006. - № 18, С. 5-11.

7. Войтоловский Н.В., Морозова В.Д., Таныгина М.В. Проблемы создания эффективной систему управления затратами [Электронный pecypc]: Евразийский международный научно-аналитический журнал «Проблемы современной экономики». - 2013. - № 3 (47) . Режим доступа: http://www.m-economy.ru. 